\title{
Yam's Potentials as Basis of Nutritional Security Programs in Underdeveloped Tropical Regions
}

\author{
José Efraín González Ramírez ${ }^{1 *}$ and Yuniel Rodríguez García ${ }^{2}$ \\ ${ }^{1}$ Plant Protection Directorate, Tropical Roots and Tubers Research Institute (INIVIT), Cuba \\ ${ }^{2}$ Genetic Resources and Breeding, Tropical Roots and Tubers Research Institute (INIVIT), Cuba
}

*Corresponding author: José Efraín González Ramírez, Plant Protection Directorate, Tropical Roots and Tubers Research Insti-

tute (INIVIT), Cuba

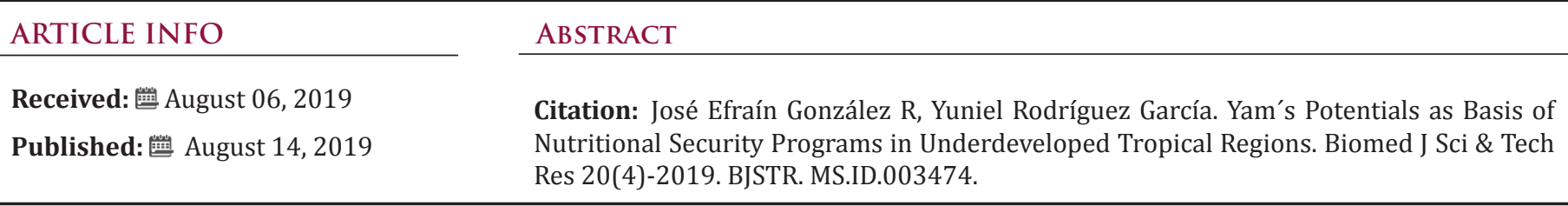

\section{Introduction}

\section{Yam: The Crop (Dioscorea spp.)}

Yam is the common name for some plant species in the genus Dioscorea (family Dioscoreaceae) that form edible tubers. It constitutes one of the main sources of food for part of the population in tropical regions [1] providing up 280 calories to about 300 million people. In terms of world production levels, yam occupies the fourth position between the roots and tubers behind the potato (Solanum tuberosum L.), cassava (Manihot esculenta Crantz), and sweet potato (Ipomoea batatas (L.) Poir.) [2,3], and it is an excellent source of carbohydrates [4-6]. In 2016, world yam production was estimated at around $66 \times 106 \mathrm{t}$ [7] with West Africa being the main producing region with up $90 \%$ of world production and a planted area around seven million hectares [8]. In America Colombia is the largest producer [9]. When analyzing FAO statistical data, it should be taken into account that some countries, such as China, do not report yam production, so the above values may be underestimated.

\section{Origin, Variability and Distribution of Yam}

The name "yam" is probably a derivation of the African tribal word "niam", which means flavor [10]. The Dioscorea genus comprises about 644 species [11,12] distributed entirely in the humid intertropical [13]. It is considered among the most primitive angiosperms [14]. About 25 species are edible and 10 are important as cash crops $[9,14,15]$. It is considered that the crop was domesticated between 7000- and 5000-years BC in parallel in West Africa, Southeast Asia and Meso and South America [16]. Due to its high genetic variability, the Dioscorea genus is divided into taxonomic sections. The 10 species that are used as food crops belong to five different sections. Table 1 shows this classification as well as its geographical origin [10,14]. Crop's classification remains in constant study. Currently, the criterion that Dioscorea rotundata Poir is a distinct subspecies Dioscorea cayenensis subsp. rotundata Poir. J. Miège), characterized by its white tubers while Dioscorea cayenensis subsp. cayenensis, characterized by yellow tubers $[9,17]$. The evolutionary processes have originated an enormous diversity of species and individuals that through the processes of permanent selection have adapted to the different conditions of the globe. This accumulated genetic variability is essential for the equilibrium of the system and constitutes what is called the planet's germplasm. If the competent authorities of many countries understood the invaluable economic and social value of their limited natural resources, among which genetic resources occupy a very high place, they would not haggle efforts to safeguard them. A continuous increase in the production and quality of food goes through the protection and effective use of plant genetic resources and this requires its collection and conservation [18]. High genetic variability gives the crop greater possibilities of coping with biotic and abiotic challenges $[19,20]$ providing the possibility of finding better adapted genotypes. The above is shown in the following examples: Yam Mosaic virus and Yam mild mosaic Virus, which are the two most important potiviruses of this crop, produce great damage to some species like D. trifida [21], while in other species such as $D$. bulbifera there are no reports of economic damage in the scientific literature. On the other hand, this crop adapts to different ecosystems and can be cultivated from sea level to up 1,800 meters 
[22,23] enabling producers to obtain acceptable yields (greater than 20 tha $^{-1}$ ) under rustic conditions.

Table 1: Yam genetic and origin diversity.

\begin{tabular}{|c|c|c|}
\hline Dioscorea spp. & Botanical section & Geographic Origin \\
\hline Dioscorea alata & Enantiophyllum & Southeast Asia \\
\hline D. rotundata & Enantiophyllum & West Africa \\
\hline D. cayenensis & Enantiophyllum & West Africa \\
\hline D. trifida & Macrogynodium & South America \\
\hline D. esculenta & Combilium & $\begin{array}{c}\text { Southeast Asia, } \\
\text { Melanesia }\end{array}$ \\
\hline D. opposita-japonica & Enantiophyllum & Japan, China \\
\hline D. bulbifera & Opsophyton & $\begin{array}{c}\text { South America, Africa, } \\
\text { Asia, Melanesia }\end{array}$ \\
\hline D. nummularia & Enantiophyllum & Melanesia \\
\hline D. transversa & Enantiophyllum & Australia, Melanesia \\
\hline D. pentaphylla & Lasiophyton & $\begin{array}{c}\text { Southeast Asia, } \\
\text { Melanesia }\end{array}$ \\
\hline
\end{tabular}

\section{Nutritional Contributions}

Yam for consumption can be cooked, boiled, roasted or fried $[23,24]$. It is a healthy, nutritional and low-fat food that supplies many of the important nutrients in the diet. Its tubers are an excellent source of energy; They contain vitamins such as thiamine, riboflavin, niacin, ascorbic acid and carotenes. In addition, they possess most of the essential amino acids: arginine, leucine, isoleucine and valine; in lesser quantity are histidine, methionine and tryptophan. Various preparation methods can be established with freshly harvested yams to give them added value and minimize product losses by reducing water activity as such, chips and flakes could be prepared [25]. Through artisanal processes that include sun drying you can obtain it is possible to obtain yam flakes or yam chips. From these flour can also be obtained, which can be reconstituted in boiling water to form a thick paste, this product is consumed in tropical areas as a source of carbohydrates [26,27]. Tambien It is also possible to obtain yogurts from yam starches resulting in acceptable texture, creamy and sweet taste [28]. Table 2 shows the nutritional composition of yam as well as its possible contribution to Recommended Dietary Allowances (RDA) according to USDA National Nutrient data base. It is important to highlight the yam's contribution to a healthy diet. The dietary fiber input contributes to lower levels of bad cholesterol (low density lipoprotein LDL) and reduces the risk of colon cancer preventing toxic compounds in food from adhering to the colon mucous membrane.

Table 2: Nutrient content from $100 \mathrm{~g}$ of fresh weight.

\begin{tabular}{|c|c|c|}
\hline Principle & Nutrient Value & RDA Percentage \\
\hline Energy & $108 \mathrm{Kcal}$ & $5 \%$ \\
\hline Carbohydrates & $27.88 \mathrm{~g}$ & $21 \%$ \\
\hline Protein & $1.53 \mathrm{~g}$ & $3 \%$ \\
\hline Total Fat & $0.17 \mathrm{~g}$ & $0.50 \%$ \\
\hline Cholesterol & $0 \mathrm{mg}$ & $0 \%$ \\
\hline
\end{tabular}

\begin{tabular}{|c|c|c|}
\hline Dietary Fiber & $4.1 \mathrm{~g}$ & $11 \%$ \\
\hline \multicolumn{3}{|c|}{ Vitamins } \\
\hline Folates & $23 \mu \mathrm{g}$ & $6 \%$ \\
\hline Niacin & $0.552 \mathrm{mg}$ & $3.50 \%$ \\
\hline Pantothenic acid & $0.314 \mathrm{mg}$ & $7 \%$ \\
\hline Pyridoxine & $0.293 \mathrm{mg}$ & $23 \%$ \\
\hline Riboflavin & $0.032 \mathrm{mg}$ & $2.50 \%$ \\
\hline Thiamin & $0.112 \mathrm{mg}$ & $9.50 \%$ \\
\hline Vitamin C & $17.1 \mathrm{mg}$ & $28.50 \%$ \\
\hline Vitamin A & $138 \mathrm{IU}$ & $5 \%$ \\
\hline Vitamin E & $0.35 \mathrm{mg}$ & $2 \%$ \\
\hline Vitamin K & $2.3 \mu \mathrm{g}$ & $2 \%$ \\
\hline \multicolumn{3}{|c|}{ Electrolytes } \\
\hline Sodium & $9 \mathrm{mg}$ & $0.50 \%$ \\
\hline Potassium & $816 \mathrm{mg}$ & $17 \%$ \\
\hline \multicolumn{3}{|c|}{ Minerals } \\
\hline Calcium & $17 \mathrm{mg}$ & $2 \%$ \\
\hline Copper & $0.178 \mathrm{mg}$ & $20 \%$ \\
\hline Iron & $0.54 \mathrm{mg}$ & $7 \%$ \\
\hline Magnesium & $21 \mathrm{mg}$ & $5 \%$ \\
\hline Manganese & $0.397 \mathrm{mg}$ & $17 \%$ \\
\hline Phosphorus & $55 \mathrm{mg}$ & $8 \%$ \\
\hline Selenium & $0.7 \mu \mathrm{g}$ & $0.50 \%$ \\
\hline Zinc & $0.24 \mathrm{mg}$ & $2 \%$ \\
\hline
\end{tabular}

In addition, being a good source of complex carbohydrates, avoiding the constant increase in blood sugar levels. For the same reason, yam recommends as healthy foods with low glycemic index. The yam tuber is a natural source of vitamins of the B group. It can contribute part of the daily requirements of pyridoxine (vitamin B6), thiamine (vitamin B1), riboflavin, folates, pantothenic acid and niacin, which are involved in various Metabolic routes. Fresh root also contains can supply approximately $29 \%$ of the recommended levels of vitamin $\mathrm{C}$; which plays an important role in the reinforcement of immune function, wound healing and bone growth, also slows cell aging Special interest should be paid to the bearing of minerals such as copper, calcium, potassium, iron, manganese and phosphorus contained in the tuber. Potassium is an important component of cellular and body fluids where it plays a fundamental role in controlling heart rate and blood pressure by counteracting the hypertensive effects of sodium.

Copper and iron are essential for the production and formation of red blood cells. The body uses manganese as a cofactor for superoxide dismutase, which is an enzyme with antioxidant activity. Table 3 compares different commercial crops where you can see that their nutritional quality is similar to that of potatoes. These two crops could also be compared in two other aspects: crop cycle and post-harvest conservation. While the potato only needs between 100-120 days to complete its cycle in contrast to the 210-330 that the yam needs, the latter can be kept for 4-6 
months at room temperature, the potato needs strict temperature and humidity controls for postharvest conservation, so the use of cold rooms are nedeed. Tied again! This high postharvest durability of yam, closely related to the natural dormancy of the crop and superior to other tropical roots and tubers such as cassava and sweet potato $[29,30]$, gives yam an important value to ensure food security in tropical regions, where it can be easily preserved. Other studies have been aimed at the nutritional comparison between the main commercial yam species [31-33] \& Table 4 shows nutritional elements of five edible yam species, where similar values are observed in the aspects evaluated.

Table 3: Comparison with other edible crops.

\begin{tabular}{|c|c|c|c|c|c|c|c|}
\hline Composition & \multicolumn{7}{|c|}{ Edible Crops } \\
\hline From $100 \mathrm{~g}$ fresh dough & Corn & Rice & Wheat & Potato & Yucca & Bean(green) & Yam \\
\hline Water & 10 & 12 & 13 & 79 & 60 & 68 & 70 \\
\hline Protein & 9,4 & 7,1 & 12,6 & 2,0 & 1,4 & 13,0 & 1,5 \\
\hline Fat & 4,74 & 0,66 & 1,54 & 0,09 & 0,28 & 6,8 & 0,17 \\
\hline Carbohidrates & 74 & 80 & 71 & 17 & 38 & 11 & 28 \\
\hline Dietary Fiber & 7,3 & 1,3 & 12,2 & 2,2 & 1,8 & 4,2 & 4,1 \\
\hline Sugar & 0,64 & 0,12 & 0,41 & 0,78 & 1,7 & 0 & 0,5 \\
\hline
\end{tabular}

Table 4: Nutritional comparison between five commercial yam species.

\begin{tabular}{|c|c|c|c|c|c|}
\hline Nutrient (\%) & D. Alata & D. Rotundata & D. Bulbifera & D. Cayenensis & D. Trifida \\
\hline Protein & $5.39-5.70$ & $4.29-5.43$ & $4.47-6.29$ & $4.24-4.27$ & $3.13-5.37$ \\
\hline Fat & $0.5-1.42$ & $0.63-2.37$ & $0.59-2.46$ & $0.59-7.86$ & $0.31-1.22$ \\
\hline Fibre & $3.65-6.36$ & $2.12-2.19$ & $1.82-5.16$ & $1.87-2.13$ & $1.94-4.91$ \\
\hline Moisture & $9.83-13.57$ & $8.08-12.17$ & $4.67-12.41$ & $9.83-12.71$ & $8.37-11.85$ \\
\hline Ash & $2.05-4.29$ & $2.13-2.76$ & $1.68-4.41$ & $3.22-3.47$ & $2.31-3.58$ \\
\hline
\end{tabular}

\section{Uses and Medicinal Values of Yam}

Dioscorea species not only enrich the diet of the rural people but also play a significant role in many cultural, religious, and social meanings, which may vary between specific ethnic groups, specifically as ethnomedicinally important source since the beginning of its cultivation $[34,35]$. Around 30 species are grown for the purpose of obtaining compounds for medical use, some with anti-thrombic effects, or for the treatment of coronary diseases and pectoral angina obtained from $D$. zingiberesis [35]. Anti-cancer compounds have been obtained from $D$. collettii var. hypoglauca and D. bulbifera [36]. In addition, clinical uses of several species for the treatment of arteriosclerosis, osteoporosis, obesity, high cholesterol and cancer have been explored [37-40]. Medicinal uses of other species include treatments for arthritis, rheumatism and menopausal disorders [33, 34,41-50]. Numerous investigations relate to obtaining secondary metabolites obtained from yam and its medicinal uses (Table 5), exemplifying the possibilities of using yam for therapeutic purposes.

Table 5: Secondary metabolites for medical use isolated in Dioscorea spp.

\begin{tabular}{|c|c|}
\hline Compounds & Uses [References] \\
\hline Diosgenin & Synthesis of steroidal drugs [40] \\
\hline Sapogenin & Anti-inflammatory effect [41] \\
\hline Saponin & Skin infections [42] \\
\hline Cyanidin & Trypsin inhibitors [43] \\
\hline Flavonoids & Skin infections [44] \\
\hline
\end{tabular}

\begin{tabular}{|c|c|}
\hline Alantoin & Ammonia Detoxification [45] \\
\hline Dioscorine & Natality control [46] \\
\hline Ohenolic Compounds & Skin infections [47] \\
\hline
\end{tabular}

\section{Conclusion}

Numerous attributes favor the growth of yam cultivation in tropical regions and in conditions of organic and environmentally friendly agriculture. Its high rusticity that allows it to be cultivated with acceptable agricultural yields in low input conditions. The important nutritional contributions in terms of carbohydrates, dietary fiber, vitamins and minerals. The potential for obtaining secondary metabolites with various medicinal uses as well as the possibility of long post-harvest life without the requirement of controlled temperature conditions make it a crop that can acquire greater importance in the contribution to nutritional and dietary security of underdeveloped tropical countries.

\section{Reference}

1. Odigbo BE, Ogbidi JB, EA Ewa (2015) A Situational Analysis Study of Yam Distribution Strategies of Farmers In Boki Local Government Area Of Cross River State, Nigeria in 2015. Journal of Economics and Sustainable Development 6(14).

2. Loko YL, A Dansi, M Tamo, AH Bokonon Ganta, P Assogba, et al. (2013) Storage Insects on Yam Chips and Their Traditional Management in Northern Benin. The Scientific World Journal : 484-536.

3. Sukal A, Kidanemariam D, Dale J, James A, R Harding (2017) Characterization of badnaviruses infecting Dioscorea spp. in the Pacific reveals two putative novel species and the first report of dioscorea bacilliform RT virus 2. Virus Research 238: 29-34. 
4. Malaurie B, M Trouslot, J Berthaud (1998) Conservation et échange de germoplasme chez les ignames (Dioscoreaspp.). In Ligname, Plante Séculaire et Culture D avenir. Actes du Séminaire International, (Eds.), J Berthaud, N Bricas, and JL Marchand pp. 135-61. CIRAD, Montepellier France.

5. Janssens M Yam (2001) In Crop Production in Tropical Africa (Eds.), R. Raemaekers pp. 229-245. Belgium: CABI.

6. Tamiru M, HC Becker, BL Maass (2008) Diversity, Distribution and Management of Yam Landraces (DioscoreaSpp.) In Southern Ethiopia. Genetic Resources and Crop Evolution 55(1): 115-131.

7. (2018) FAOSTAT. Food and Agriculture Organization of the United Nations. [On line] Disponible desde.

8. Asala SW, ES Ebukiba ES (2016) Profitability of yam production in Southern Guinea Savanna zone of Nigeria. Net Journal of Agricultural Science 4(1): 9-14

9. Pérez Camacho J, L Raz (2017) Flora de la República de Cuba Dioscoreaceae: Botanischer Garten und Botanisches Museum Berlin.

10. Mignouna HD, Abang MM, R Asiedu (2008) Genomics of Tropical Crop Plants. Moore PH, Ming R (Eds.), Genomics of Yams, a Common Source of Food and Medicine in the Tropics pp. 549-570. Springer, New York.

11. Burkill IH (1960) The organography and the evolution of the Dioscoreaceae, the family of the yams. J Linn Soc Lond Bot 56: 319-412.

12. Ngo Ngwe MFS, S Joly, Bourge M, Brown S, DN Omokolo (2014) Nuclear DNA Content Analysis of Four Cultivated Species of Yams (Dioscorea Spp.) From Cameroon. Journal of Plant Breeding and Genetics 2: 87-95.

13. Malaurie B, Trouslot MF, J Berthaud (1989) Conservatrio et echage de germoplasme chez les ignames (Dioscorea spp.) Berthaud J, Bricas $\mathrm{N}$, Marchand JL (Eds.), Lìgname, plante seculaire et cultura dàvenir, Montepellier France pp. 135-161.

14. Lebot V (2008) Tropical Root and Tuber Crops: Cassava, Sweet Potato, Yams and Aroids. Paris University, France p. 351

15. León J (2000) Botánica de los cultivos tropicales. $3^{\text {rd }}$ (edn.). Rev y aum. San José, Costa Rica. IICA, Colección de libros y materiales educativos p. 255.

16. González, ME (2012) El ñame (Dioscorea spp.) Características, usos y valor medicinal. Aspectos de importancia en el desarrollo de su cultivo. Cultivos Tropicales 33: 5-15.

17. Price EJ, Bhattacharjee R, Lopez Montes A, PD Fraser (2017) Metabolite profiling of yam (Dioscorea spp.) accessions for use in crop improvement programmes. Metabolomics 13(11): 144.

18. Martin I (2000) Conservación de recursos fitogenéticos. Instituto Nacional de Investigación y Tecnología Agraria y Alimentaria.

19. Coursey DG (1983) Chan HC (Eds.), Handbook of tropical foods. Marce Dekker Inc, New York, USA.

20. Frison EA, Cherfas J, T Hodgkin (2011) Agricultural Biodiversity Is Essential for a Sustainable Improvement in Food and Nutrition Security. Sustainability 3: 238-253.

21. Costanzo A, P Bàrberi (2014) Functional agrobiodiversity and agroecosystem services in sustainable wheat production. A review. Agronopmical Sustainble Development 34(2): 327-348.

22. Filho F de A, Nicolini C, Resende R de O, Genira P de A, Pio Ribeiro G, et al. (2013) The complete genome sequence of a Brazilian isolate of yam mild mosaic virus. Archives of Virology 158(2): 515-518.

23. Garedew B, Haile B, A Ayiza (2017) Distribution, Diversity and Potential Production of Yams (Dioscorea spp.) in Sheko District, Southwest Ethiopia. American Journal of Life Sciences 5(3): 86-92.

24. Galani VJ, DM Patel (2017) A Comprehensive Phytopharmacological Review of Dioscorea bulbifera Linn. International Journal of Environmental Sciences and Natural Resources 4(5): 555650.
25. Adeniji MO, Shoyinka SA, Ikotun T, Asiedu R, Hughes JdA, et al. (2012) Yield loss in Guinea yam (Dioscorea rotundata Poir.) due to infection by yam mosaic virus (YMV) genus Potyvirus. Ife Journal of Science 14: 237-243.

26. Oluwole OB, Awororin SO, Henshaw F, Elemo GN, OAT Ebuehi (2013) Assessment of microbial changes and nutritional qualities of extruded white yam (Dioscorea rotundata) and Bambara groundnut (Vigna subterranean) blends. Food and Nutritional Science 4: 100-107.

27. Omohimi C, Piccirillo C, Roriz M, Ferraro V, Vasconcelos WM, et al. (2017) Study of the proximate and mineral composition of different Nigerian yam chips, flakes and flours. Journal of Food Sciences and Technology 55(1): 42-51.

28. Ayodele BC, Bolade MK, MA Usman (2013) Quality characteristics and acceptability of "amala" (yam-based thick paste) as influenced by particle size categorization of yam (Discorea rotundata) flour. Food Sciences and Technology 19(1): 35-43

29. Omohimi C, Piccirillo C, Ferraro V, Roriz MC, Omemu MA, et al. (2019) Safety of Yam-Derived (Dioscorea rotundata) Foodstuffs-Chips, Flakes and Flour: Effect of Processing and Post-Processing Conditions Foods 8(1): 12

30. Tortoe Ch, Akonor PT, J Ofori (2018) Starches of two water yam (Dioscorea alata)varieties used as congeals in yogurt production. Food Science \& Nutrition 7(3): 1053-1062.

31. Adejo PE (2017) Post-Harvest Management Practices of Yam and Farmers Information Needs in the North-Central of Nigeria. J Nutraceuticals Food Sci 2(3): 9.

32. Kodwo Ansah IG, Ehwi J, S Arkoh Donkoh (2018) Effect of postharvest management practices on welfare of farmers and traders in Tamale metropolis and Zabzugu District, Ghana. Food Science \& Technology 4(1): 1475916.

33. Shajeela PS, Mohan VR, Jesudas LL, PT Soris (2011) Nutritional and Antinutritional Evaluation Of Wild Yam (Dioscorea spp.) Tropical and Subtropical Agroecosystems 14: 723-730.

34. Bekele A, E Bekele (2018) Proximate and Mineral Composition Variability in Ethiopian Yam (Dioscoreaspp). Journal of Food and Nutrition Sciences 6(1): 12-17.

35. Mulualem T, Mekbib F, Hussein S, E Gebre (2018) Analysis of Biochemical Composition of Yams (Dioscorea spp.) Landraces from Southwest Ethiopia. Agrotechnology 7: 177.

36. Kumar S, Das G, Shin HS, JK Patra (2017) Dioscorea spp. (A Wild Edible Tuber): A Study on Its Ethnopharmacological Potential and Traditional Use by the Local People of Similipal Biosphere Reserve, India. Frontiers in Pharmacology 8: 52.

37. Obidiegwu JE, EM Akpabio (2017) The geography of yam cultivation in southern Nigeria: Exploring its social meanings and cultural functions. Journal of Ethnic Foods 4(1): 28-35.

38. Gong G, Qin Y, W Huang (2011) Anti-thrombosis effect of diosgenin extract from Dioscorea zingiberensis C.H. Wright in vitro and in vivo. Phytomedicine 18(6): 458-463.

39. Lu C, Nan K, M Jiao (2009) Inhibition of cellular proliferation and induction of apoptosis in human esophageal carcinoma cell lines by extracts of Dioscorea bulbifera L and Chinese angelica. Journal of Nanjing Medical University 23(6): 398-402

40. Begum AT, S Anbazhakan (2013) Evaluation of antibacterial activity of the mucilage of Dioscorea esculenta (Lour.) Burkill. Int J Mod Biol Med 4(3): 140-146.

41. Chandrasekara A, TJ Kumar (2016) Roots amd tuber crops as functional foods: a review on phytochemical constituents and their potential health benefits. International Journal of Food Sciences.

42. Cui H, Li T, Wang L, SuY, CJ Xian (2016) Dioscorea bulbifera polysaccharide and cyclophosphamide combination enhance anticervical cancer effect 
and attenuates immunosuppression and oxidative stress in mice Sciences Reports 5: 19185.

43. Asha KI, GM Nair (2005) Screening of Dioscorea species for diosgenin from southern western ghats of India. Indian Journal of Plant Genetic Resources 18(2): 227-230.

44. Martin FW (1969) The species of Dioscorea containing sapogenin Economic Botany 23(4): 373-379.

45. Nayaboga E, Tripathi JN, Manoharan R, L Tripathi (2014) Agrobacteriummediated genetic transformation of yam (Dioscorea rotundata): an important tool for functional study of genes and crop improvement. Frontiers in Plant Science 5: 463.

46. Hou WC, Chen HJ, YH Lin (2000) Dioscorins from different Dioscorea species all exhibit both carbonic anhydrase and trypsin inhibitor activities. Botanical Bulletin of Academia Sinica (Taipei) 41: 191-196.

\section{ISSN: 2574-1241}

DOI: 10.26717/BJSTR.2019.20.003474

José Efraín González Ramírez. Biomed J Sci \& Tech Res

This work is licensed under Creative

Commons Attribution 4.0 License

Submission Link: https://biomedres.us/submit-manuscript.php
47. Poornima GN, RV Ravishankar (2007) In vitro propagation of wild yams, Dioscorea oppositifolia (Linn) and Dioscorea pentaphylla (Linn). African Journal of Biotechnology 6(20): 2348-2352.

48. Fujihara S, M Yamaguchi (1978) Effects of allopurinol [4-hydroxyprazolo $(3,4-d)$ pyrimidine] on the metabolism of allantoin in soybean plants. Plant Physiology 62(1): 134-138.

49. Adetoun A, T Ikotun (1989) Antifungal activity of dihydrodioscorine extracted from a wild variety of Dioscorea bulbifera L. Journal of Basic Microbiology 29(5): 265-267.

50. Kumar S, PK Jena (2014) Edible medicinal non-timber forest products from floral wealth of tribal Odisha. Sabujima 22: 41-44.

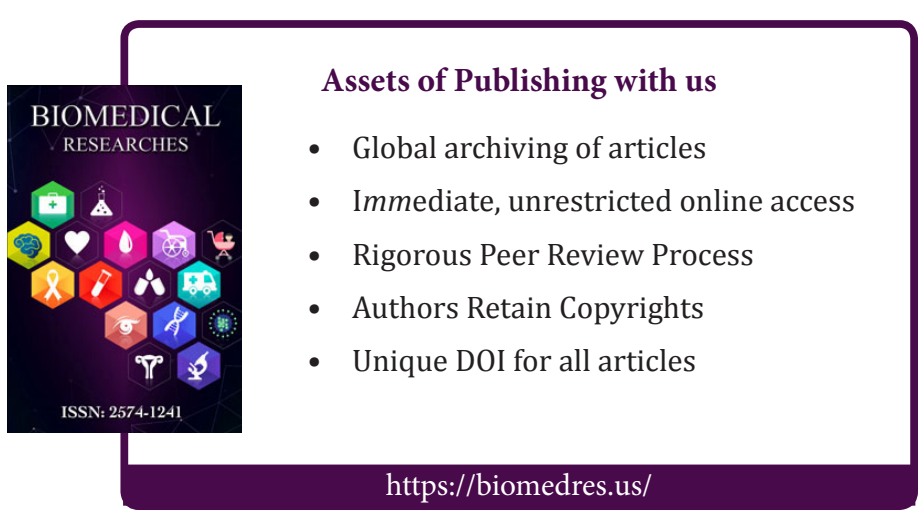

